\title{
Issues in the Care of Farm Animals: Current History of the Movement in Selected States
}

Jennifer N. Dunn

West Virginia University

Follow this and additional works at: https://researchrepository.wvu.edu/etd

\section{Recommended Citation}

Dunn, Jennifer N., "Issues in the Care of Farm Animals: Current History of the Movement in Selected States" (2011). Graduate Theses, Dissertations, and Problem Reports. 351.

https://researchrepository.wvu.edu/etd/351

This Thesis is protected by copyright and/or related rights. It has been brought to you by the The Research Repository @ WVU with permission from the rights-holder(s). You are free to use this Thesis in any way that is permitted by the copyright and related rights legislation that applies to your use. For other uses you must obtain permission from the rights-holder(s) directly, unless additional rights are indicated by a Creative Commons license in the record and/ or on the work itself. This Thesis has been accepted for inclusion in WVU Graduate Theses, Dissertations, and Problem Reports collection by an authorized administrator of The Research Repository @ WVU. For more information, please contact researchrepository@mail.wvu.edu. 
Issues in the Care of Farm Animals: Current History of the Movement in Selected States

\author{
Jennifer N. Dunn
}

Thesis submitted to the Davis College of Agriculture, Natural Resources and Design at West Virginia University in partial fulfillment of the requirements for the degree of

\author{
Master of Science \\ in \\ Agricultural and Extension Education
}

\author{
Harry N. Boone, Jr., Ph.D., Chair \\ Deborah Boone., Ph.D. \\ Jean M. Woloshuk, Ed.D. \\ Division of Resource Management \\ Morgantown, West Virginia \\ 2011
}

Keywords: Humane Treatment of Animals, Animal Welfare, Animal Rights, Prevention of Animal Cruelty 


\author{
ABSTRACT \\ Issues in the Care of Farm Animals Current History \\ of the Movement in Selected States \\ Jennifer N. Dunn
}

Many animal care practices commonly accepted as a regular part of the agricultural industry are being questioned by organizations advocating for the care of farm and companion animals. The use of gestation crates for pregnant sows, veal crates for veal calves, and battery cages for egg-laying hens are being banned in some states in the United States. While appearing to be a modern phenomenon, animal rights/animal welfare issues actually can be found throughout history. The purpose of the study was to trace the history of the care of farm and companion animals movement in the United States. This included the identification of major events in the movement, as well as legislation that has been enacted to insure the proper care of farm and companion animals. The movement for the care of farm and other domestic animals can be connected to legislation or executive orders in at least seven states. In addition numerous states have begun the reevaluation of the current status, including potential legislation, for the protection of farm and companion animals. Most states that have passed legislation were influenced by out of state animal rights organizations. California received national media attention with the passing of Proposition Two which prohibited the use of gestation crates for pregnant sows, crates for veal calves, and battery cages for egg-laying hens. California was the first state to ban battery cages for egg-laying hens. Florida, Arizona, Colorado, Michigan, and Ohio have also passed state legislation regarding the treatment of animals. 


\section{ACKNOWLEDGEMENTS}

I would like to thank God for all the great people who have walked into my life during this process and have encouraged and helped me complete my thesis. I would like to thank my parents who always encouraged me to go after my dreams and showing me the importance of continuing my education. I would like to thank Dr. Debby Boone and Dr. Woloshuk for all the time they have spent helping me complete my thesis. I would like to thank Dr. Harry Boone for encouraging me to complete this thesis even when I felt the end was nowhere in sight. Thank you all very much. I really appreciate all your help and encouragement. 


\section{TABLE OF CONTENTS}

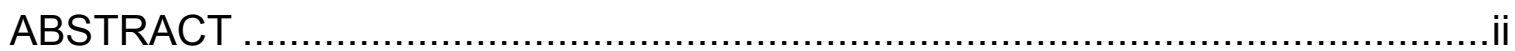

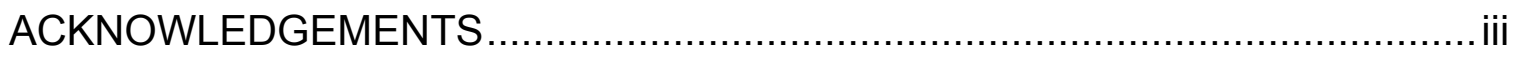

TABLE OF CONTENTS ….....................................................................

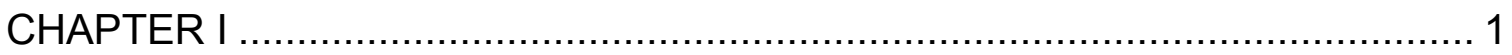

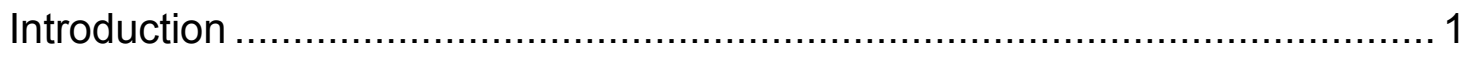

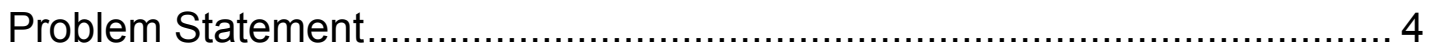

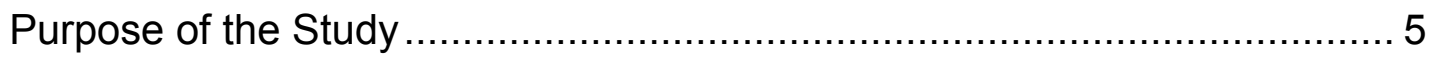

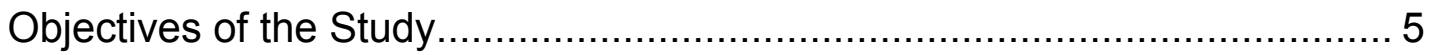

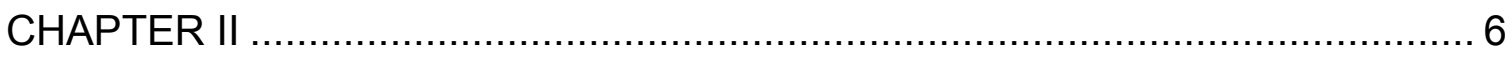

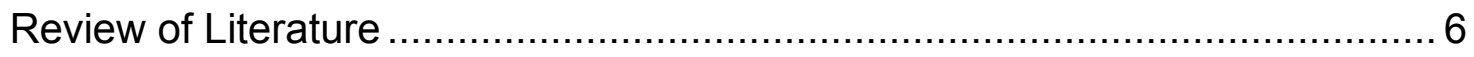

Key Legislation in the United States ……........................................... 9

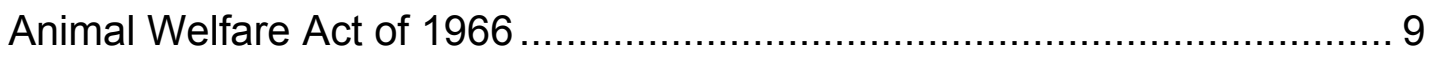

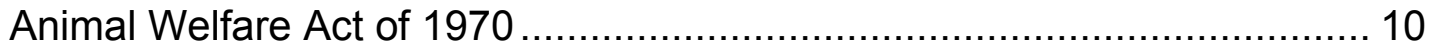

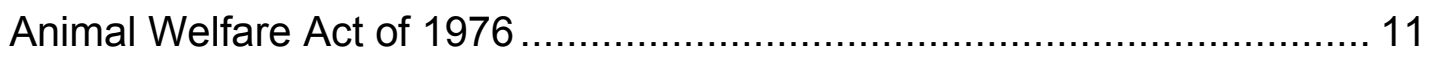

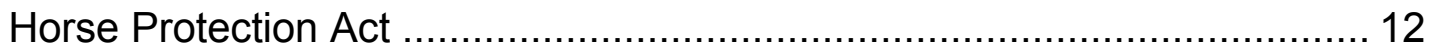

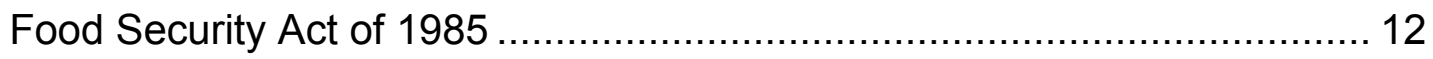

Food, Agriculture, Conservation, and Trade Act of 1990.......................... 13

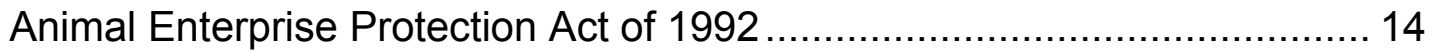

Farm Bill 2002 and Animal Fighting Prohibition Enforcement Act of 2007 .. 14

Humane Methods of Livestock Slaughter .............................................. 15

Key Humane Treatment of Animal Organizations in the United States ........... 16

People for the Ethical Treatment of Animals (PETA) .............................. 16 
Humane Society of the United States ................................................. 17

The American Society for the Prevention of Cruelty to Aniamls ................ 18

American Humane Association ............................................................. 19

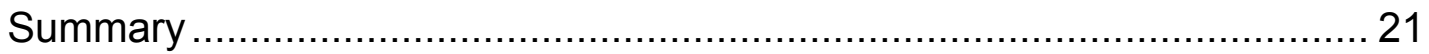

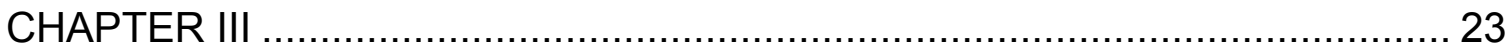

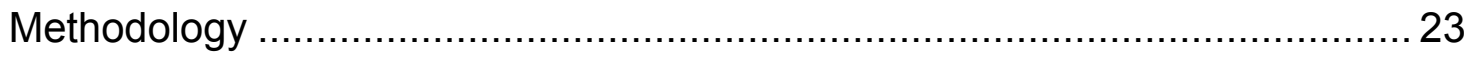

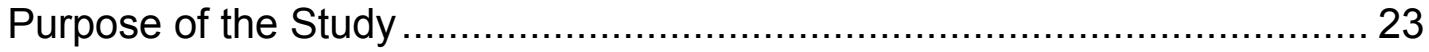

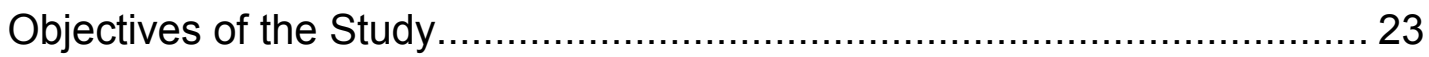

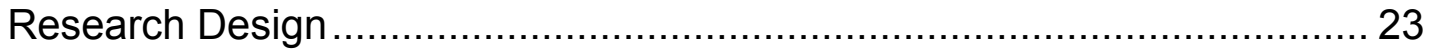

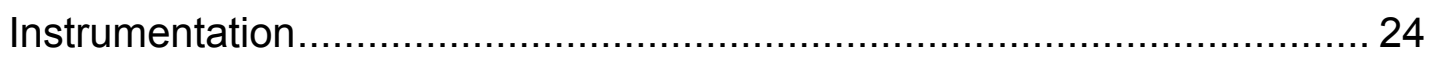

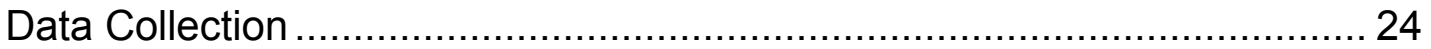

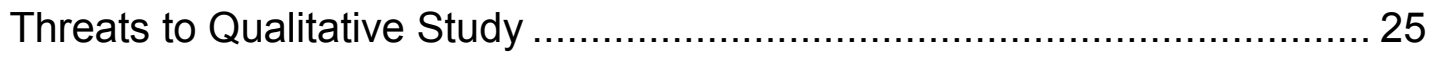

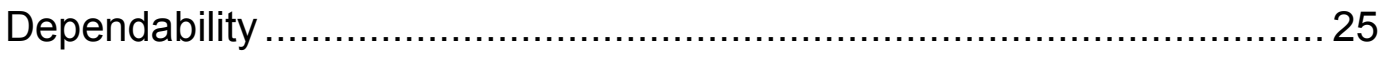

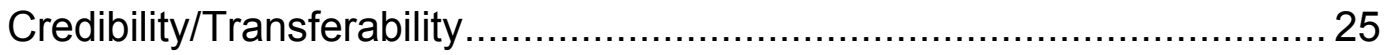

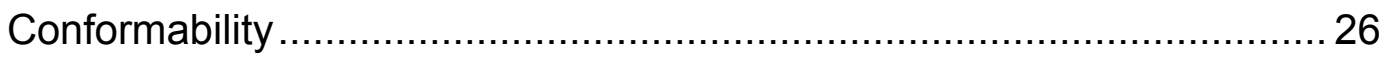

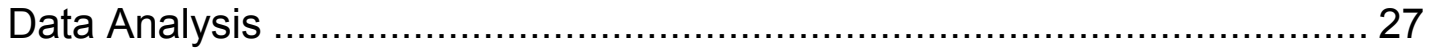

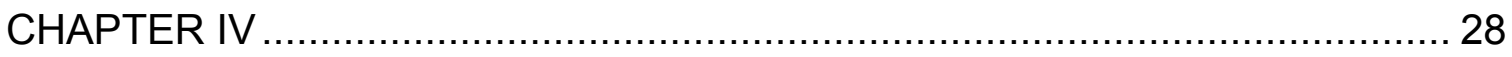

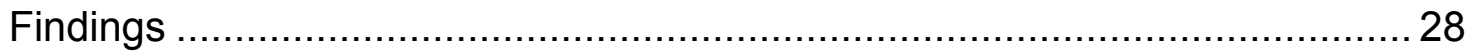

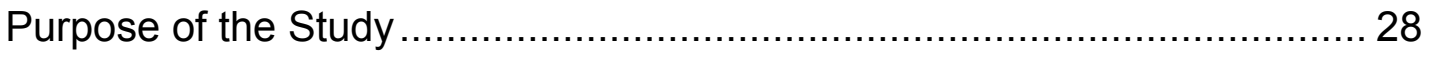

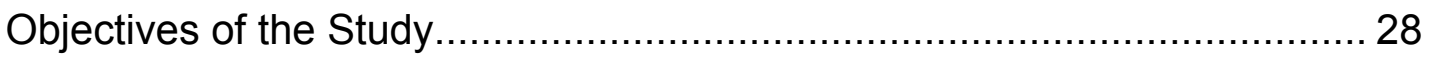

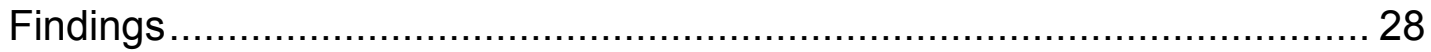

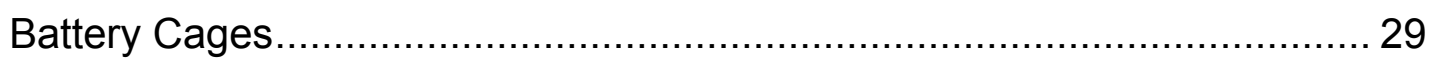

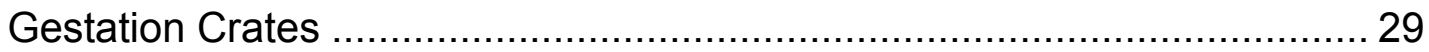




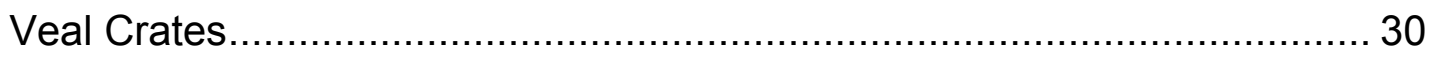

States with Animal Production Legislation ............................................... 31

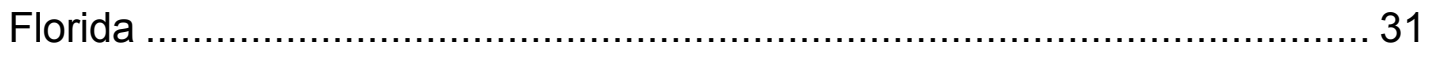

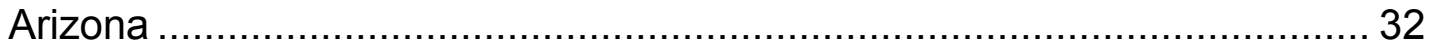

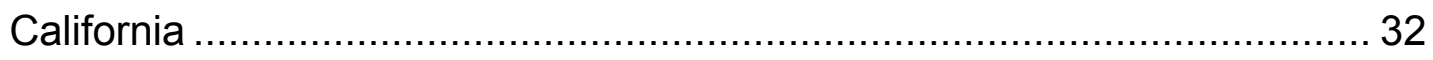

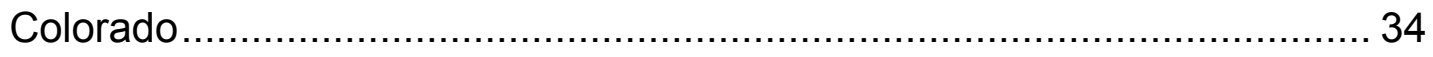

Ohio

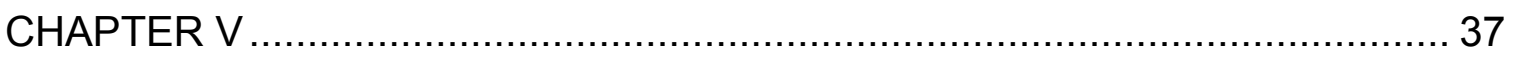

Summary, Conclusions, and Recommendations ..................................... 37

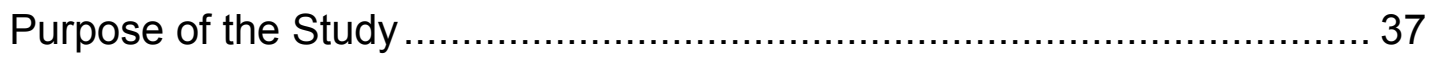

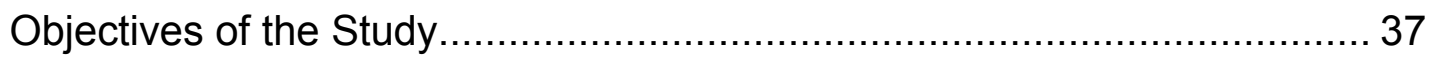

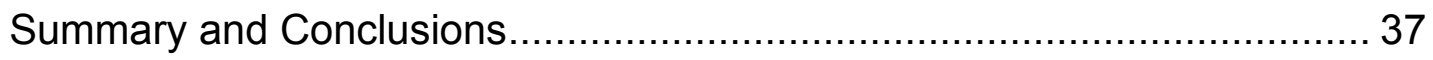

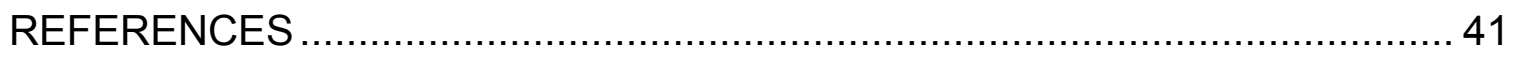

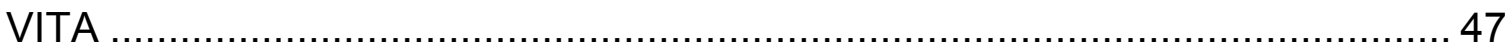




\section{CHAPTER I}

\section{Introduction}

The care of farm and companion animals is a widely debated topic that has many views and beliefs. On one end of the spectrum animal rights activists believe that humans do not have the right to use animals for food, clothing, entertainment and vivisection (Lin, 2011). On the opposite end of the issue you have individuals that believe that animals deserve no moral consideration (Lin, 2011). Often these opposing views tend to polarize specific segments of the United States population.

Over the years there has been a proliferation of organizations that seek to inform the public about their beliefs and values on the care of farm and companion animals. While these organizations seem to agree about one issue, enforcing the humane treatment of all animals, they disagree on the actions that should be taken to reach their goal. Many times these organizations have specifically targeted the agriculture industry.

The organizations advocating for the care of farm and companion animals are usually divided into two groups: animals rights and animal welfare organizations. While these two groups advocate for the care of farm and companion animals, there are very diverse distinctions separating these groups.

Animal rights organizations believe that humans do not have the right to use animals for food, clothing, entertainment and vivsection (Lin, 2011). Animal 
rights organizations believe that humans do not have the right to slaughter and eat animals. They seek to eliminate the use of animals entirely. Most animal rights organizations see animals as their equals (Animal Rights Information, 2010).

Animal rights organizations have been known to use a variety of methods to gain public attention and express their views and beliefs. As a result of the methods they chose to gain public attention, some animal rights organizations are referred to as radical animal rights organizations (Sherry, 1994). The Humane Society of the United States (HSUS) and People for the Ethical Treatment of Animals (PETA) are two examples of animal rights organizations (Sherry, 1994).

The primary mission of animal welfare organizations is to make certain that animals are treated humanely regardless of their purpose (Animal Rights Information, 2010). Animal welfarism is defined as "the belief that humans have the right to use animals as we see fit as long as they are treated humanely" (Lin, 2011). While humans have the right to slaughter and eat animals, the animal welfarists believe that the animals should be treated humanely before and during the slaughter. Animal welfarists also seek to eliminate practices such as confining calves in veal crates, housing pregnant sows in gestation crates, and debeaking chickens. Animal welfare organizations often take more traditional steps to prevent animal cruelty (Sherry, 1994). The American Society for the Prevention of Cruelty of Animals (ASPCA) and the American Humane 
Association (AHA) are two examples of animal welfare organizations (Sherry, 1994).

Many of these organizations have carried their advocacy into the political arena. As a result of this advocacy, a number of states have passed legislation regulating the treatment of farm and other companion animals. Florida, in 2002, passed legislation to ban the use of gestation crates for pregnant sows. Arizona, in 2006, passed legislation to ban the use of gestation crates for pregnant sows as well as the use of crates for veal calves. California, in 2008, passed the Treatment of Farm Animals Act which prohibited the use of gestation crates for pregnant sows, housing veal calves in veal crates, and keeping egg-laying hens in battery cages. Ohio, in 2009, passed Issue Two which created the Ohio Livestock Care Standards Board (OLCSB) to establish a set of standards to improve the animal welfare of livestock animals. The OLCSB will establish standards for the way egg-laying hens, veal calves, and pregnant sows are housed and produced.

While well-intentioned, these regulations have had and will continue to have a major impact on the agriculture industry in the United States. The complete impact of many of these regulations is still unknown because many of the regulations have not yet taken full effect. It is estimated that egg producers in California would be greatly impacted since about sixty-six percent of the state's egg needs are produced within the state (Promar International, 2009). The egg 
industry in California has an important role in the states economics because it produces about five billion eggs yearly (Shapiro, 2008).

To understand the future, one must look at the past. It is important that all segments of the agriculture industry understand the history behind the care of farm and other companion animals movement. Not only should a well-informed agriculturist understand the movement, but they should be aware of the present and future impacts of the movement on the industry. What methods must be followed to assure the approved care of farm animals comply with local, state, or federal legislation? What conditions resulted in legislation regulating the care of farm and other companion animals in states such as California, Florida, Arizona, and Ohio?

\section{Problem Statement}

Many animal care practices commonly accepted as a regular part of the agricultural industry are being questioned by organizations advocating for the care of farm and companion animals. The use of gestations crates for pregnant sows, veal crates for veal calves, and battery cages for egg-laying hens are being banned in some states in the United States. In some locations these organizations have resorted to legislation to impose their views. This legislation will have an impact on the agricultural industry. The American agriculture industry has a major role in the feeding of the United States population, along with a portion of the world. How do we accomplish this role and maintain practices that take into consideration the proper care of farm and companion 
animals? One solution is education, however, before education can be effective the agricultural industry must make a concerted effort to understand the mission and beliefs of the organizations advocating for the care of farm and companion animals.

\section{Purpose of the Study}

The purpose of this study was to trace the history of the care of farm and companion animals movement in the United States. This includes the identification of major events in the movement, as well as legislation that has been enacted to insure the proper care of farm and companion animals.

\section{Objectives of the Study}

The objectives of this were reflected in the following research questions:

- What events, past and present, shaped the care of farm and companion animals movement in the United States?

- What states have implemented legislation regulating the humane treatment of animals used for agricultural production? 


\section{CHAPTER II}

\section{Review of Literature}

The care of farm and companion animals is a widely debated topic with many diverse views and beliefs. The different views on the methods of humane treatment animals often result in diverse plans of action to achieve acceptance of their views. Groups advocating for the care of farm and companion animals can be separated into two different categories: animal rights and animal welfare organizations.

Animal rights organizations are against all forms of animal use by humans (Nussbaum, 2004). People for the Ethical Treatment of Animals (PETA) and the Humane Society of the United States (HSUS) are two examples of animal rights organizations (Nussbaum, 2004).

Traditional animal welfare organizations encourage the humane care of animals as well as find ways to prevent animal cruelty (Sherry, 1994). The American Society for the Prevention of Cruelty to Animals (ASPCA) and the American Humane Association are two examples of traditional animal welfare organizations (Nussbaum, 2004).

Concern for care of farm and companion animals is not a recent phenomenon. Ancient Hindu and Buddhist scriptures can be interpreted to advocate for animal rights by providing ethical reasons for maintaining a 
vegetarian diet (Lin, 2011). Animal rights issues have remained a part of history since this time.

Animal rights issues have been present through many historical periods including the antiquity, medieval, renaissance, enlightenment, Romanic, and Victorian ages. During the Medieval period Saint Kevin of Glendalough, an animal activist, stated, "I do not desire, that God's creatures be moved on my account, for the Lord can otherwise assist my place; and moreover, all animals about these mountains are mild and domesticated towards me, and they should feel sorrowful" (Animal Rights History, n. d. d, ๆ 5).

During the Enlightenment period Humphrey Primatt an animal activist of that time stated:

"What should we think of a stout and strong Man that should exert his fury and barbarity on a helpless and innocent Babe? Should we not abhor and detest that man, as a mean, cowardly, and savage wretch, unworthy the stature and strength of a man? No less mean, cowardly, and savage is it, to abuse and torment the innocent Beast, who can neither help himself or avenge himself; and yet has as much right to happiness in this world as a child can have; nay, more right, if this world be his only inheritance." (Animal Rights History, n. d. a, đ 2)

Jeremy Bentham, an animal activist during the Romanic Age, stated "The day may come, when the rest of the animal creation may acquire those rights 
which never could have been withholden from them but by the hand of tyranny" (Animal Rights History, n. d. b, ๆ 3). Bentham also went on to say "The question is not, Can they reason? nor Can they talk? but, can they suffer?" (Animal Rights History, n. d. b, ๆ 3).

Mark Twain was born in 1835 at the beginning of the Victorian Age (1837 to 1901). Twain had a very successful writing career which did not involve his animal welfare views. However, towards the end of Twain's life he began to write about a variety of issues that the world was facing at that time. One of those issues was the process of vivisection in animal research. Twain, in a letter to the editor of the Animals' Friend Magazine, stated, "I believe I am not interested to know whether vivisection produces results that are profitable to the human race or doesn't. To know that the results are profitable to the race would not remove my hostility towards it" (Animal Rights History, n. d. c, \ 2).

The care of farm and other domestic animals movement began years ago and has remained a topic of debate throughout history. The debate has resulted in legislation in a number of states. In 1828 the state of New York passed the first anti-cruelty to animals' law in the United States. By 1921 every state in the United States had passed some form of anti-cruelty to animals' law (Ours, 1990). 


\section{Key Legislation in the United States}

\section{Animal Welfare Act of 1966}

The Animal Welfare Act of 1966 was one of the earlier animal cruelty acts to receive national attention. This act was passed as a result of a family's lost Dalmatian dog, Pepper, in 1965. Pepper disappeared from her family's farm in Pennsylvania and later was believed to be found in New York in what was considered a dog farm. Pepper's owner drove to New York but was not allowed to enter the farm to identify the dog. Later the family discovered that Pepper was sold to a medical research facility and was used in research, euthanized, and cremated. This family's lost pet provided the stimulus to pass the Animal Welfare Act of 1966. The Act provided protection for animals used in laboratories as well as introduced the topic of stolen pets.

The Animal Welfare Act of 1966 states (United States Department of Agriculture, 2011):

[Dogs, cats, and other animals intended for research or experimental use] Be it enacted by the Senate and House of Representatives of the United States of America in Congress assembled. That, in order to protect the owners of dogs and cats from theft of such pets, to prevent the sale or use of dogs and cats which have been stolen, and to insure that certain animals intended for use in research facilities are provided humane care and treatment, it is essential to regulate the transportation, purchase, 
sale, housing, care, handling, and treatment of such animals by persons or organizations engaged in using them for research or experimental purposes or in transporting, buying, or selling them for such use (\$3).

\section{Animal Welfare Act of 1970}

The Animal Welfare Act of 1966 was amended in 1970 to include additional regulations for individuals and organizations that use animals for experimentation and for the exhibition or sale of pets. Retail pet stores, however, were not included in this amendment (Sherry, 1994). The Animal Welfare Act of 1970 included all warm blooded animals being used in experimental facilities established by the United States Secretary of Agriculture (United States Department of Agriculture, 1970). The term "animal" was described as follows:

The term 'animal' means any live or dead dog, cat, monkey (nonhuman primate mammal), guinea pig, hamster, rabbit, or such other warm-blooded animal, as the Secretary may determine is being used, or is intended for use, for research, testing, experimentation, or exhibition purposes, or as a pet; but such term excludes horses not used for research purposes and other farm animals, such as but not limited to livestock or poultry used or intended for use for improving animal nutrition, breeding, management, or production efficiency, or for improving the quality of food or fiber... (T 10) 
The Secretary of Agriculture was required to develop regulations for record keeping and humane treatment of animals when being transported and/or used for experimentation in research facilities (United States Department of Agriculture, 1970).

\section{Animal Welfare Act of 1976}

The Animal Welfare Act of 1976 amended the act of 1970 to include regulations regarding the use of animals for fighting purposes. Those regulations made it illegal for any individual or organization transporting animals for the purpose of animal fighting (Sherry, 2009). The act addressed the use of animals for fighting purposes in the following manner: (United States Department of Agriculture, 1976):

It shall be unlawful for any person to knowingly sell, buy, transport, or deliver to another person or receive from another person for purpose of transportation, in interstate for foreign commerce, any dog or other animal for purposes of having the dog or other animal participate in an animal fighting venture. (\$ 49)

This amendment extended humane animal treatment methods to carriers and intermediate handlers of animals. Before any animal can be transported it must be examined by a licensed veterinarian to determine that the animal is completely healthy and free of any infectious disease or physical illness (Sherry, 1994). 


\section{Horse Protection Act}

The Horse Protection Act was established in 1990 to prohibit individuals or organizations from using a soring technique on horses to attempt to gain a competitive edge in shows and sales. Soring is a practice used to draw attention to a horse's gait, which when practiced incorrectly can be extremely painful and cruel. "Soring involves irritating the horse's forelegs with injections and applying chemicals or mechanical restraints" (Sherry, 2009, p. 103). This practice is used to gain a competitive edge because a sored horse will quickly lift their front legs to try to relieve the discomfort. This act is regulated by the Animal and Plant Health Inspection Service (APHIS) which is a division of the USDA. APHIS works directly with the horse industry to help ensure that the regulations in this act are continually being followed (United States Department of Agriculture, 2010). A Designated Qualified Person (DQP), accredited through the USDA, is used to enforce the act by conducting unannounced examinations on horses beings shown or sold at events in the United States. The DQPs are USDAaccredited veterinarians with equine experience or they are farriers, horse trainers, or other knowledgeable horsemen who have been formally trained and licensed by USDA-certified horse industry organizations or associations (United States Department of Agriculture, 1990).

\section{Food Security Act of 1985}

The Food Security Act of 1985, also known as the Improved Standards for Laboratory Animals Act, increased regulations for animals used in research 
facilities to help reduce any pain or distress the animal may experience. The Animal Welfare Act of 1976 created regulations on the transportation of animals but did not include animals inside research facilities (Sherry, 2009). The Food Security Act of 1985 provided additional humane care standards for housing, sanitation, and ventilation inside experimental research facilities (United States Department of Agriculture, 1985). The act also included provisions that no animal should undergo any experimental treatment without the proper veterinary care as well as sufficient recovery time for each animal in between experimental treatments (Sherry, 1994). This act also mandated that an Institutional Animal Care and Use Committee be established "at each institution whose function would be to evaluate experimental protocols to determine if the protocols followed made the best use of the animals" (Sherry, 2009, p. 104). These committees were to help ensure that experimentation already completed was not replicated in future experimental studies.

\section{Food, Agriculture, Conservation, and Trade Act of 1990}

The Food, Agriculture, Conservation, and Trade Act of 1990 established a holding period of five days for dogs and cats being held at humane shelters and other types of holding facilities to allow time for animals to be found by their owner or be adopted by other individuals before they could be sold to a dealer (Sherry, 2009). It also established regulations requiring animal dealers to obtain and provide each animal's background to the receiver of the animal. The information required on the certification must include: "a description of the dog or 
cat being provided, the species and breed or type of such, the sex of the animal, the date of birth if known, the color and any distinctive marking and any other information that the Secretary of Agriculture regulated as appropriate" (United States Department of Agriculture, 1990, p.1).

\section{Animal Enterprise Protection Act of 1992}

The Animal Enterprise Protection Act of 1992 provided protection for animal research facilities by establishing penalties for individuals and/or organizations who cause damages or interrupt the experimentation of the facility. The term enterprise in this act is defined by Animal Rights: A Reference Handbook as a commercial or academic enterprise that uses animals for food, fiber production, agriculture, research, or testing (Sherry, 2009). If an animal enterprise experiences any type of damage such as stolen goods or any type of loss of experimental property that exceeds ten thousand dollars the individual or organization responsible will face large fines and penalties (United States Department of Agriculture, 1992).

\section{Farm Bill 2002 and Animal Fighting Prohibition Enforcement Act of 2007}

The Farm Bill of 2002 and the Animal Fighting Prohibition Enforcement Act of 2007 created stricter regulations and penalties for individuals or an organization found to be transporting animals for the purpose of animal fighting. The Farm Bill 2002 stated that it was "a misdemeanor to ship a bird in interstate commerce for the purpose of fighting or to sponsor a fight using birds shipped via interstate commerce" (Sherry, 2009, p. 105). The Animal Fighting Prohibition 
Enforcement Act of 2007 created stricter regulations that made it "illegal to buy, sell, transport, or deliver into interstate or foreign commerce any sharp instrument meant to be attached to a bird's leg for use in an animal-fighting venture" (Sherry, 2009, p. 106).

\section{Humane Methods of Livestock Slaughter}

The Humane Slaughter Act, first signed into effect in 1958, addressed the way cattle, calves, horses, mules, sheep, swine, and other livestock animals must be unconscious to decrease the amount of pain and distress an animal would experience when slaughtered. This Humane Slaughter Act states, "Congress determined that the use of humane methods of handling and slaughtering livestock prevents needless suffering of animals and results in safer and better working conditions for employees in slaughter establishments" (United State Department of Agriculture, 2011b). Methods appropriate at the time to render an animal unconscious were a single blow or gunshot, or an electrical, chemical, or any other method that would be rapid and effective (Sherry, 2009).

The USDA helps ensure that humane slaughtering practices are followed through the Food Safety and Inspection Service (FSIS), a branch of the USDA. FSIS enforces the humane treatment of animals at every federally inspected slaughter establishment by having a veterinarian on staff and a slaughter line inspector (United States Department of Agriculture, 2001). The veterinarian and slaughter line inspector observe the methods used by the facility and take appropriate action if necessary. They are required to report all incidents of 
inhumane methods being used in the slaughtering establishment (USDA Regulations on Slaughtering, 2011).

\section{Key Humane Treatment of Animal Organizations in the United States}

Throughout history a number of organizations have been founded to help ensure that anti-cruelty legislation was developed and followed properly. Some organizations have set in motion legislative action for the welfare of animals. Some of the organizations have increased their membership with various campaigns to help gain public attention to different aspects of animal cruelty. The following organizations are just a few of the most recognized organizations that have been established to promote the care of farm and companion animals.

\section{People for the Ethical Treatment of Animals (PETA)}

People for the Ethical Treatment of Animals (PETA) was organized in 1980 by Ingrid Newkirk and Alex Pacheco to increase awareness of animal rights. It has grown into one of the largest animal rights organizations in the United States. PETA focuses most of its attention on decreasing the amount of suffering animals face in the clothing trade, research laboratories, factory farms, and entertainment industry (People for the Ethical Treatment of Animals, 2011). PETA promotes their views and beliefs with major protest campaigns usually resulting from undercover investigation. Newkirk felt the need to create PETA after reading Animal Liberations written by Peter Singer. Animal Liberation is often considered the bible of the animal rights movement (Sherry, 1994). 
PETA's first undercover investigation, the Spring Monkey Case, was conducted in 1981 and involved Alex Pacheco's employment at Edward Taub's animal research laboratory (Sherry, 1994). Taub's research study was on sensory nerves in the brain and involved the use of monkeys. Pacheco took pictures and documented the treatment of the monkeys. He later informed local law enforcement about the research being conducted. Since this undercover investigation PETA has conducted numerous investigations to draw attention to what they believe is animal cruelty and to change the way animals are used and treated.

\section{Humane Society of the United States}

The Humane Society of the United States (HSUS) was established in 1954 as a result of a conflict between members of the American Humane Association (AHA) on the issue of animal shelters being required to send animals to research facilities. Robert J. Chenoweth and Oliver M. Evans helped establish the Humane Society of the United States (Humane Society of the United States, 2011). HSUS' first major successful involvement with legislation was the Animal Welfare Act of 1966 that involved the protection of stolen animals from being directly used for experimental purposes.

Today HSUS is considered the largest animal rights organization in the United States in terms of the number of members and the amount of donations received. The mission statement of HSUS is "Celebrating Animals, Confronting Cruelty" (Humane Society of the United States, 2011). HSUS works to reduce 
suffering and to create meaingful social change for animals (Humane Society of the United States, 2009). They accomplish their goal by gaining public attention through education, advertisitng, and working with other corporations to investigate what they believe to be inhumane treatment of animals. The major issues targeted by HSUS inculde: dogfighting, puppy mills, factory farming, different hunting practices, commerical fur trading, and the slaugthering of horses in America.

HSUS has been an influence in the passage of legislation in several states including California, Florida, Arizona, and Colorado regarding animals used for agricultural purposes. They are now actively involved in the state of Ohio focusing on practices involving veal calves, pregnant sows, and battery chickens.

\section{The American Society for the Prevention of Cruelty to Animals}

The American Society for the Prevention of Cruelty to Animals (ASPCA), the first animal welfare organization developed in the United States, was founded by Henry Bergh in 1866. Their mission is "to provide effective means for the prevention of cruelty to animals throughtout the United States" (ASPCA, 2011, p.1).

ASPCA work involves community outreach, animal health services, and anti-cruelty initiatives. Their nonviolent approaches to prevent animal cruelty involve law enforcement practices such as; fines, jail sentences, and counseling of individuals to help prevent acts of animal cruelty. One way the ASPCA publicly demonstrates their role against animal cruelty is through their reality tv 
show "Animal Cops" on the Animal Planet Network. The show demonstrates actions taken by the ASPCA to protect animals.

The ASPCA advocates that animals used for agricultural purposes should always be treated in a humane manner and should never be put in any long term situtations of pain and distress. ASPCA supports Humane Farm Animal Care (HFAC), an organization approved by the United States Department of Agriculture, that helps to ensure the humane treatment of livestock including those bred for human consumption.

\section{American Humane Association}

The American Humane Association was founded in 1877 with the mission to create a more humane and compassionate world by ending abuse and neglect of children and animals (American Humane Association, 2011a). The key programs and initiatives to help protect animals include: Red State Animal Emergency Services, Second Chance Fund, Shelter Services and National Programs, Farm Animal Program/American Humane Certified, and Film and TV Unit/ "No Animals were Harmed."

The Red State Animal Emergency Services was established in 1916 to assist wounded animals in the United States Army during World War 1 (American Humane Association, 2011b). Today this services offers aid to animals that become victims of natural and manmade disasters. Over the years this part of the organization has grown to now include numerous emergency response 
vehicles that were designed to help animals in a variety of situations (American Humane Association, 2011b).

Second Chance Fund was created as a result of the Red State Animal Emergency Services because many of the animals that were helped needed serious medical attention. The Second Chance Fund helps pay for medical expenses and other materials that are needed for the animal before they can be placed back into the wild or adopted by a family (American Humane Association, 2011e). The Shelter Services and National Programs are part of the organization that provides a variety of education and training programs for individuals who plan a career in animal services or volunteer at animal shelters. The programs include ways to help gain communities support, promote adoptions, and reduce euthanasia rates just to name a few (American Humane Association, 2011e).

Farm Animal Program/American Humane Certified is the first welfare certification program established in the United States to help assure farm livestock are treated humanely. The American Humane Certified program provides third-party, independent verification that certified producers' care and handling of farm animals meet the science-based animal welfare standards of American Humane Assocation (American Humane Association, 2011c).

The film and TV unit/ "No Animals Were Harmed" was created to help ensure that animals used for movies and TV entertainment were treated humanely throughout the filming process. The American Humane Association puts the "No Animals Were Harmed" at the end of each movie that passes their 
humane treatment standards while filming. Certified Animal Safety Representatives are on the filming site to ensure humane treatment of the animals, not only in Hollywood but throughout the world (American Humane Association, 2011d).

The American Humane Assocation works to create a more humane and caring society by protecting children and animals from abuse, neglect and maltreatment situtations. One division of the American Humane Assocation works directly with children while the other division helps prevent and educate the public about issues of abuse, neglect, and maltreatment of animals in the United States. The American Humane Assocation works to eliminate the mistreatment of children and animals because they feel the two are very closely related and both are often victims in domestic abuse situtations. The American Humane Assocation (2011a) states they are: "a leader in researching the problem, raising public awarness, and most important, providing tools for decision makers, social service providers, animal care and control professionals, veterinarians, parents and concerned citizens to recognize problems and take appropriate steps to end abuse and protect its victims" ( $p 1)$.

\section{Summary}

The Animal Welfare Act of 1966 gained media attention in the United States and influenced the continuation of the animal rights movement. Since the passage of the Animal Welfare Act of 1966 it has been ammended numerous times to help ensure the humane treatment of animals. Legislation documented 
in this research has illustrated protection for companion animals, agricultural animals, and animals used for research purposes.

A variety of organizations for the care of agricultural and domestic animals have been organized in the United States beginning as early as 1866 . The animal right organizations have included: People for the Ethical Treatment of Animals (PETA), Humane Society of the United States (HSUS) and the American Humane Association just to name a few. These organizations have had an influence in the United States by supporting legislations to help ensure humane practices on animals. 


\section{CHAPTER III}

\section{Methodology}

\section{Purpose of the Study}

The purpose of this study was to trace the history of the care of farm and companion animals movement in the United States. This includes the identification of major events in the movement, as well as legislation that has been enacted to insure the proper care of farm and companion animals.

\section{Objectives of the Study}

The objectives of this were reflected in the following research questions:

- What events, past and present, shaped the care of farm and companion animals movement in the United States?

- What states have implemented legislation regulating the humane treatment of animals used for agricultural production?

\section{Research Design}

A qualitative research design was used that included a combination of historical and document analysis techniques. "Qualitative researchers seek to understand a phenomenon by focusing on the total picture rather than breaking it down into variables" (Ary, Jacobs, Razavieh, \& Sorenson, 2006, p. 31). According to Ary et al., (2006) "historical research analyzes documents and artifacts to gain insight into what has happened in the past" (p. 33). This 
research study was historical because the major humane treatment for animals events and legislation were documented to determine the start of the movement as well as how it has progressed today. "Content analysis focuses on analyzing and interpreting recorded material within its own context" (Ary et al., 2006, p. 32).

\section{Instrumentation}

In many qualitative studies, the human investigator is the primary instrument for the collection of data (Ary et al., 2006). This was the case for this research effort. The researcher holds a Bachelor of Science degree from The Ohio State University in Agricultural Education and Extension, an Associate's degree in Animal Science, and completed student teaching in a high school agricultural education program. The researcher completed a summer internship on a 400 head purebred Angus cattle farm in Ohio. The researcher was also active in 4- $\mathrm{H}$ as a youth and showed market steers, market hogs, market lambs, feeder calves, as well as rabbits.

\section{Data Collection}

Research procedures included keeping all the findings in a notebook throughout the entire process. This research included the exploration of events that took place in the beginning of the animal welfare movement in the United States. Various websites were used including: United States Department of Agriculture (USDA), Farm Bureau, Humane Society of the United States (HSUS), People for the Ethical Treatment of Animals (PETA), The American Society for the Prevention of Cruelty to Animals (ASPCA), and American Humane 
Association. Published books and research articles were also used to help gain greater understanding into the views and beliefs surrounding the animal rights movement. The various state government web sites were used to document the different animal welfare legislation and actions. In order to keep this research unbiased opposing views were documented and presented in the research findings.

\section{Threats to Qualitative Study}

\section{Dependability}

Dependability is "the consistency or stability of the results; the extent to which the same general results would occur with different sets of people or in different settings and time periods" (Ary et al., 2006 p. 632). Two procedures were used to insure the dependability of the study. An audit trail of all the steps and procedures was maintained for the entire study. A variety of diverse sources were used to help establish a non-bias approach in correctly documenting the events that have taken place throughout the care of farm and companion animal welfare movement in the United States. After the data were collected it was coded and recoded to increase accuracy. This type of double checking of data also helps in assisting in the development of credibility as well as dependability.

\section{Credibility/Transferability}

Credibility refers to the degree to which the researcher's observations are believable. The background of the researcher is the first step in establishing the 
research's credibility. The researcher was experienced in the area that was studied. A variety of sources of data were used along with numerous data collection methods. The findings were presented to a panel of experts to "verify" the researcher's interpretations of the data were correct.

Transferability is "the degree to which the findings of a study can be generalized to other contexts or to other groups" (Ary et al., 2006, p. 640). In order to establish transferability efforts were made to develop a greater understanding of the various opposing views that tend to surround the care of farm and companion animal movement in the United States. The populations for the study were not selected on the basis of their uniqueness, specific context or setting, or unique historical experiences. This allows for transferability of the results.

\section{Confirmability}

Conformability refers to the degree the results are neutral and free from bias. Conformability was addressed by developing an audit trail so the study can be traced or recreated. To avoid bias, the researcher presented her previous experience and qualifications. Three phases of data collection; historical document review, interviews, and observations; were used to triangulate the research findings. The results were also presented to a committee of experts to examine the degree the results were neutral and free from bias. 


\section{Data Analysis}

The data were analyzed and categorized after all data was collected. The findings were categorized by sections according to topics discussed. After topics were decided on, correlations were examined and an overall theme regarding the issues were addressed. The data were compared and contrasted. The data were also coded and recoded for consistency. 


\section{CHAPTER IV}

\section{Findings}

\section{Purpose of the Study}

The purpose of this study was to trace the history of the care of farm and companion animals movement in the United States. This includes the identification of major events in the movement, as well as legislation that has been enacted to insure the proper care of farm and companion animals.

\section{Objectives of the Study}

The objectives of this were reflected in the following research questions:

- What events, past and present, shaped the care of farm and companion animals movement in the United States?

- What states have implemented legislation regulating the humane treatment of animals used for agricultural production?

\section{Findings}

The treatment of egg-laying hens, veal calves, and pregnant sows in agriculture have been the main issues for many organizations advocating for the care of farm and companion animals. Legislative actions in a number of states have specifically addressed these farming practices. 


\section{Battery Cages}

It is estimated that 95 percent of all eggs are produced in conventional caged systems in the United States (United Egg Producers Certified, n.d. b.) The use of cages for egg production has a variety of benefits including the protection of the hen from various predators and the prevention of different diseases that can be spread by wild birds. The use of cages for egg production can also help the producer observe each hen daily to recognize potential illnesses and take the necessary steps to prevent its spread throughout the whole flock. Individuals opposed to battery cages hold the opinion that by placing a number of hens in a small cage, the hens are not able to undergo their natural behaviors such as nesting, normal foraging, scratching, dust bathing behavior, perching, and roosting. Because caged birds cannot engage in these "natural" behaviors, steps have been taken to eliminate the use of the cages.

In November 2008 the state of California was the first state to ban the use of battery cages in egg-laying hen operations. The ban will be fully implemented by January 1,2015 . Michigan banned battery cages with the passing of state legislation in October 2009. In some situations the legislation has been a result of actions taken by various animal rights organizations in the United States regarding the treatment of livestock animals.

\section{Gestation Crates}

Gestation crates used in the swine industry are small and often prohibit the sow from turning around or moving freely. This issue has generated attention 
because some of the larger swine operations often keep their pregnant sows in gestation crates for the duration of the pregnancy. The use of gestation crates for pregnant sows has been banned in seven states in the United States. The seven states include: Arizona, California, Colorado, Florida, Maine, Michigan, and North Carolina (Humane Society of the United States, 2009). The uses of farrowing crates, however, are not included in this ban. Farrowing crates are used for pregnant sows before and after they give birth as a way to protect the piglets from being killed as the sow attempts to lay down.

\section{Veal Crates}

The procedures used to raise veal calves have also received national attention. In some operations veal calves are kept in small stalls and, in some instances, tied up to prevent them from turning around. Veal calves are kept in individual stalls to help decrease the amount of contact between other calves and reduce the spread of disease. The practice increases the level of calf care because the calves are observed on a daily basis. However, some veal operations have made the use of veal crates extremely small in order to produce a larger number of calves in a given location and have attracted negative attention from animal rights organizations. A number of states including California, Colorado, Arizona, Florida, and Oregon, have passed legislation to ban the use of veal crates in the production of veal. This encourages the use of group housing in the production of veal. 


\section{States with Animal Production Legislation}

\section{Florida}

In November 2002, Florida passed Amendment 10 banning the practice of gestation crates for breeding swine. The legislation passed with 54 percent of the voters in favor of the act. This farming practice ban was the first in the United States because the residents of Florida perceived the practice to be cruel towards breeding pigs (Animal Rights Foundation of Florida, n.d.). HSUS, Fund for Animals, and Farm Sanctuary were just a few of the major supporters of this legislation in Florida (American Veterinary Medical Association, n.d.). The organizations, along with a number of other volunteers, worked together to gather the signatures needed to put the amendment on the ballot in Florida. According to the Constitution of the State of Florida, Article X, Section 21, states:

Inhumane treatment of animals is a concern of Florida citizens.

The people of the state of Florida hereby limit the cruel and inhumane confinement of pigs during pregnancy as provided herein. (a) It shall be unlawful for any person to confine a pig during pregnancy in an enclosure, or to tether a pig during pregnancy, on a farm in such a way that she is prevented from turning around freely. (Animal Rights Foundation of Florida, n.d.) 


\section{Arizona}

Arizona voters passed the Humane Treatment of Farm Animals Act also referred to as Propositions 204 in November of 2006. This legislative act prohibited the confinement of pregnant sow in gestations crates and veal calves being raised in crates. The Humane Treatment of Farm Animals Act will take full effect on January 1, 2013 to provide adequate time for livestock producers in Arizona to make the necessary changes to comply with this act of legislation. The pork and veal industries in the state of Arizona are extremely small with only one large industrial pork operation in the state at the time this legislation was passed in 2006. The Humane Society of the United States (HSUS), Arizona Humane Society, Animal Defense League of Arizona, and Farm Sanctuary worked together to help led efforts to pass the legislation in Arizona. (Humane Society of the United States, 2011).

\section{California}

California passed the Treatment of Farm Animals Statute (also referred to Proposition Two) in November of 2008. This Statute will prohibit the confinement of pregnant sows in gestation crates, veal calves in veal crates, and egg-laying hens in battery cages. The rationale given for the passage of the statute included the change in the way farm animals are kept and will help ensure that animals are able to freely turn around, lay down, stand up, and have the ability to fully extend their limbs (League of Women Voters of California Education Fund, 2008). The Treatment of Farm Animals Statute is scheduled to be in full effect 
on January 1,2015 . This will provide adequate time for livestock producers in California to make the necessary changes to comply with this statute.

The University of California Agricultural Issue Center stated that the veal production in California is extremely small, as well as, the production of swine. They were unclear if the use of gestation crates was commonly practiced in these operations, therefore the primary effect of the legislation will be in the poultry industry (League of Women Voters of California Education Fund, 2008). This legislation resulted in California being the first state to ban the use of battery cages for egg-laying poultry operations. The economic result of this legislation is still unclear however it is projected that the legislation will increase production costs for the farms. As a result it will increase the price consumers will have to pay for food products and could force farmers out of business. The University of California Agriculture Issues Center suggested the following result for Proposition 2:

Our analysis indicates that the expected impact would be the almost complete elimination of egg production in California within the five-year adjustment period. Non-cage production costs are simply too far above the costs of the cage systems used in other states to allow California producers to compete with imported eggs in the conventional egg market. The most likely outcome, therefore, is the elimination of almost all of the California egg 
industry over a very few years. (United Egg Producers Certified, n.d. a., p. 5).

\section{Colorado}

Governor Bill Ritter signed Senate Bill 201 in May 2008 which placed a ban on the use of veal crates for calves, as well as, gestations crates for breeding pigs (The Humane Society of the United States, 2008). Senate Bill 201 will phase out the use of veal creates for calves by 2012 and the use of gestation crates used for breeding swine by 2018 (The Humane Society of the United States, 2008).

The bill had the backing of HSUS and other Colorado agricultural organizations. President and CEO of HSUS Wayne Pacelle states, "Americans demand humane treatment of animals, including animals raised for food. With this measure, adversaries turned into allies to advance animal welfare concerns, through cooperation, progress on this important issue can indeed belong to everyone" (The Humane Society of the United States, 2008 p.1). Colorado has also agreed to continue discussions with HSUS in the future to phase out the use of battery cages for egg-laying hens. As long as this type of open discussion continues HSUS has withdrawn a ballot initiative petition to phase out the use of battery cages through legislation. The summary of Colorado's Senate Bill 201 states that calves raised for veal and pregnant members of the porcine species be kept in a manner that permits animals to stand up, lie down, and turn around without touching the sides of their enclosure. It extends this requirement to 
animals until slaughter for calves raised for veal and until birth for pregnant members of the porcine species. It specifies penalties for violations. It also sets dates by which such method of confinement shall be implemented.

\section{Ohio}

Issue 2, supporting the creation of the Ohio Livestock Care Standards Board (OLCSB) was passed in November of 2009. The purpose of the OLCSB was to construct a set of standards regarding the care and welfare of livestock in Ohio. The standards would help provide the safety of the food supply and protect the farms of Ohio.

Issue 2 was passed as a result of the HSUS's attempt to implement their own standards on how livestock in Ohio should be produced. HSUS agreed with the passage of Issue 2 as a way to improve the welfare of farm animals. The OLCSB will create standards for the way egg-laying hens, veal calves, and pregnant sows are housed and produced. The standards will be based on best management practices, veterinary standards, animal health data, and the protection of local food supplies (Ohio Farm Bureau Federation, 2010).

The agreement states that recommendations will be made to the OLCSB regarding transitioning to group housing for veal calves by 2017, phasing out the use of gestations crates by December 31, 2025, banning the use of battery cages and providing for the correct treatment of downer cattle (Ohio Farm Bureau Federation, 2010). OLCSB's goal is to collect recommendations from all interested parties and create standards that will improve the welfare of livestock 
animals used for agricultural purpose. The HSUS has publicly agreed to not pursue a ballot initiative regarding any key points in the agreement as long as Ohio develops standards regarding the animals listed in the agreement and has them in effect by the deadline date. 


\section{CHAPTER V}

\section{Summary, Conclusions, and Recommendations}

\section{Purpose of the Study}

The purpose of this study was to trace the history of the care of farm and companion animals movement in the United States. This includes the identification of major events in the movement, as well as legislation that has been enacted to insure the proper care of farm and companion animals.

\section{Objectives of the Study}

The objectives of this were reflected in the following research questions:

- What events, past and present, shaped the care of farm and companion animals movement in the United States?

- What states have implemented legislation regulating the humane treatment of animals used for agricultural production?

\section{Summary and Conclusions}

Organizations involved in the care of farm and companion animals in the United States can be traced nearly 150 years to the creation of the American Society for the Prevention of Cruelty to Animals (ASPCA). Since then a number of organizations have been developed to protect animals from cruelty. Many of these organizations help gain public attention by showing disturbing videos and pictures of how some livestock producers mistreat their animals. This creates a 
misconception that this is a common practice by all livestock producers. As a result of these misconceptions these organizations continue to have an influence on agriculture practices in the United States. The Humane Society of the United States (HSUS), People for the Ethical Treatment of Animals (PETA), and the American Humane Association are just a few organizations that have been organized throughout the years in the United States.

There has been a proliferation of organizations involved in the care of farm and companion animals in the United States since 1866 and the establishment of the ASPCA. Animal rights and animal welfare organizations both want to see animal cruelty in the United States stopped however; they each have extremely different approaches to their goal. Combined these two groups have influenced how animals are cared for and housed in the United States.

The care of farm and companion animals movement can be connected to legislation or executive orders in at least seven states. In addition, numerous states have begun the reevaluation of the current status, including the introduction of legislation, for the protection of animals. Most states that have passed legislation were influenced by out of state organizations. California received national media attention with the passing of Proposition Two which prohibited the use of gestation crates for pregnant sows, crates for veal calves, and battery cages for egg-laying hens. California was the first state to ban battery cages for egg-laying hens. Florida, Arizona, Colorado, Michigan, and Ohio have also passed state legislation regarding the treatment of animals. 
The success of the care of farm and companion animal movement in influencing policies, order, and/or legislation will provide the motivation for many organizations to continue, and possibly expand, their operations. The Animal Welfare Act of 1966 was one of the earliest pieces of legislation that had support from the movement. As a result of the success of HSUS in passing the Animal Welfare Act of 1966, other organizations have expanded their efforts to exert an influence on animal protection legislation. Efforts in Florida, Arizona, Colorado, and Ohio have been documented. The common theme in these states included the ban of gestation crates used for pregnant sows, crates used for veal calves, and battery cages used for egg-laying hens.

\section{Recommendations}

While the care of farm and companion animals movement has had major success in influencing legislation in several states, just how informed are the general public in these states? Are the major stakeholders in the agriculture

community, as well as the average consumer of agricultural products, up-to-date on the activities surrounding the food supply? It is recommended that a series of studies be conducted to determine the knowledge and perceptions of the major stakeholders in the agriculture community, as well as, the average consumer of agricultural products, on animal rights movements.

It is recommended that this study be expanded to cover care of farm and companion animals activities in each of the fifty states. This would document agricultural legislation in each state. Knowledge of what has occurred will allow 
other states to develop a proactive plan of action in the establishment of regulations to prevent animal cruelty.

Legislation in Florida, California, Michigan, Colorado, Arizona, and Ohio had similar themes including the banning of gestation crates for pregnant sows, crates for veal calves, and the use of battery cages for egg-laying hens. It is recommended that other states review the legislation in their respective states and develop a proactive approach to establishing recommendations or legislation to protect the rights of the animals and avoid potential conflict with the care of farm and companion animals organizations. An example of a proactive approach for a state would be the establishment of a committee to recommend humane methods for producers to follow when raising livestock. The regulations would help livestock operations remain profitable and continue their production of livestock.

The care of farm and companion animals movement in the United States has had and will continue to have a great influence on the way animals are raised and produced. It is important for the future of animal agriculture to create humane practices for producers to follow in order to insure an adequate food supply in the United States as well as the world. 


\section{REFERENCES}

American Humane Society. (2011a). About us. Retrieved from http://www.americanhumane.org/about-us/

American Humane Society. (2011b). Emergency services. Retrieved from http://www.americanhumane.org/animals/programs/emergency-services/

American Humane Society. (2011c). Farm animal welfare. (2011). Retrieved from http://www.americanhumane.org/animals/programs/farm-animalwelfare.html

American Humane Society. (2011d). No animals were harmed. Retrieved from http://www.americanhumane.org/animals/programs/no-animals-wereharmed/

American Humane Society. (2011e). Second chance fund .Retrieved from http://www.americanhumae.org/animals/professional-resources/forshelter-professionals/grant-programs/second-chance-fund.html

American Veterinary Medical Association. (n. d.). Campaign to outlaw sow housing in Florida advances. Retrieved from http://www.avma.org/onlnews/javma/oct02/021001a.asp

Animal Rights Foundation of Florida. (n. d.). Florida's historic ban on gestation crates. Retrieved from http://www.animalrightsflorida.org/initiative.html.

Animal Rights History. (n. d. a). Animal rights quotes: Humphrey Primatt.

Retrieved from http://www.animalrightshistory.org/animal-rightstimelines/animal-rights-quotes/quotes-enlightenment/1776-humphreyprimatt.htm?zoom_highlight=Primatt 
Animal Rights History. (n. d. b). Jeremy Bentham. Retrieved from http://www.animalrightshistory.org/1785-1837-animal-rights/romanticb/ben-jeremy-bentham/1789-morals-legislation.htm

Animal Rights History. (n. d. c). Mark Twain on scientific research. Retrieved from http://www.animalrightshistory.org/1837-1901-animal-rights/victoriant/twa-mark-twain/1900-scientificresearch.htm?zoom_highlight=Mark+Twain

Animal Rights History. (n. d. d). Saint Kevin of Glendalough. Retrieved from http://www.animalrightshistory.org/0485-1450-animal-rights/medievalk/kevin-of-glendalough/6-7thc-kevin-of-glendalough.htm.

Animal Rights Information. (2010). Retrieved from http://www.ehow.com/about_5365561_animal-rights-information.html.

Ary, D., Jacobs, L. C., \& Razavieh, A., Sorensen, C. (2006). Introduction to research in education ( $7^{\text {th }}$ ed.). California: Thomson Wadsworth.

ASPCA. (2011). About us. Retrieved from http://www.aspca.org/About-Us.aspx Humane Society of the United States (2008). Gov. Ritter Signs Historic Farm Animal Welfare Measure. Retrieved from http://www.humanesociety.org/news/press_releases/2008/05/gov_ritter_si gns_farm_animal_measure_051408.html

Humane Society of the United States (2011). About us. Retrieved from http://www.humanesociety.org/about/ Humane Society of the United States. (2009). Veal crates, gestation crates and battery cages banned. (2009, November 6). Retrieved from 
http://www.humanesociety.org/news/press_releases/2008/11/prop_2_inter national_110608.html

League of Women Voters of California Education Fund. (2008). Proposition 2 Standards for Confining Farm Animals State of California. Retrieved from http://www.smartvoter.org/2008/11/04/ca/state/prop/2/

Lin, D. (2011). Historical Timeline of the Animal Rights Movement. Retrieved from http://animalrights.about.com/od/animalrights101/a/TimelineModern.htm Nussbaum, C. R. (2004). Animal Rights Current Debates and New Directions . New York : Oxford University Press, Inc. .

Our, J. L. (1990). Influences of the animal rights movement on animal production agriculture research in land grant institutions as perceived by experiment station directors. Unpublished master's thesis. West Virginia University, Morgantown, WV.

People for the Ethical Treatment of Animals. (2011). About PETA. Retrieved from http://www.peta.org/about/default.aspx.

Promar International. (2009). Impacts of banning cage egg production in the United States. Author: Alexandria, VA. Retrieved from http://www.unitedegg.org/pdf/Promar_Study.pdf.

Shapiro, P. (2008). Making History for Animals: YES! on Prop 2. Retrieved from http://animalrights.about.com/od/proposition2ca2008/a/YesOnProp2.htm

Sherry, C. (1994). Animal Rights: A Reference Handbook. Santa Barbara: ABCCLIO, LLC, INC. 
Sherry, C. (2009). Animal Rights A Reference Handbook Second Editions .

Santa Barbara: ABC-CLIIO, LLC.

United Egg Producers Certified. (n. d. a.). American egg farming. Retrieved from http://www.unitedegg.org/information/pdf/American_Egg_Farming.pdf United Egg Producers Certified. (n. d. b.). The egg industry and animal welfare:

A science-based approach. Retrieved from http://www.unitedegg.org/information/pdf/Egg_Industry_Animal_Welfare_ Brochure.pdf

United States Department of Agriculture. (1970). Public Law 91-579: Animal Welfare Amendments of 1970. Retrieved from http://awic.nal.usda.gov/nal_display/index.php?info_center=3\&tax_level=4 \&tax_subject=182\&topic_id=1118\&level3_id=6735\&level4_id=11093\&level 5_id=0\&placement_default $=0$

United States Department of Agriculture. (1976). Public Law 94-279: Animal Welfare Amendments of 1976. Retrieved from http://awic.nal.usda.gov/nal_display/index.php?info_center=3\&tax_level=4 \&tax_subject=182\&topic_id=1118\&level3_id=6735\&level4_id=11094\&level 5_id=0\&placement_default $=0$

United States Department of Agriculture. (1976). Public Law 99-198: Food Security Act of 1985. Retrieved from http://awic.nal.usda.gov/nal_display/index.php?info_center=3\&tax_level=4 \&tax_subject=182\&topic_id=1118\&level3_id=6735\&level4_id=11095\&leve 15_id=0\&placement_default $=0$ 
United States Department of Agriculture. (1985). Public Law 99-198, Food Security Act of 1985, Subtitle F - Animal Welfare. Retrieved from http://awic.nal.usda.gov/nal_display/index.php?info_center=3\&tax_level=4 \&tax_subject=182\&topic_id=1118\&level3_id=6735\&level4_id=11095\&level 5_id=0\&placement_default $=0$

United States Department of Agriculture. (1990). Public Law 101-624: Food, Agriculture, Conservation, and Trade Act of 1990 - Protection of Pets. Retrieved from http://awic.nal.usda.gov/nal_display/index.php?info_center=3\&tax_level=4 \&tax_subject=182\&topic_id=1118\&level3_id=6735\&level4_id=11096\&level 5_id=0\&placement_default $=0$

United States Department of Agriculture. (1992). Animal Enterprise Protection Act of 1992. . Retrieved from http://www.nal.usda.gov/awic/legislat/pl102346.htm United States Department of Agriculture. (2001). Key Facts: Humane Slaughter. . Retrieved from http://www.fsis.usda.gov/Fact_Sheets/Key_Facts_Humane_Slaughter/inde x.asp

United States Department of Agriculture. (2010). Transportation, Sale, And Handling Of Certain Animals. Retrieved from http://www.gpo.gov/fdsys/pkg/USCODE-2009-title7/html/USCODE-2009title7-chap54.htm 
United States Department of Agriculture. (2011a). Animal Welfare Act. Retrieved from

http://awic.nal.usda.gov/nal_display/index.php?info_center=3\&tax_level=3 \&tax_subject=182\&topic_id=1118\&level3_id=6735\&level4_id=0\&level5_id= 0\&placement_default $=0$

United States Department of Agriculture. (2011b). USDA Regualtions on Slaughtering. Retrieved from http://www.ehow.com/list_6874102_usdaregulations-slaughtering.html 
Jennifer Dunn

2011

West Virginia University

Davis College of Agriculture, Natural Resources, and Design Masters of Science

Morgantown WV

Major: Agriculture and Extension Education

2009

The Ohio State University

College of Agriculture

Bachelors of Science

Columbus, Ohio

Major: Agricultural Education and Extension

Minor: Agriculture Production 